\title{
Forget Bárbara Virgínia? A ForerunNer FILMMAKER BeTWEen Portugal AND Brazil
}

\author{
Paula Sequeiros \& Luísa Sequeira
}

\begin{abstract}
Bárbara Virgínia was a forerunner film director in Portugal and the Festival de Cannes. Starting artistically as a diseuse and actress, she directed a feature film and a documentary in her youth, in 1946. Bárbara emigrated to Brazil in 1952 to work on radio and television, the country where she settled, formed a family, eventually abandoning the stages, and died in 2015 . For this socio-biography, we collected and analysed public and private memory documents, a research interview and conversations with her family. To construct our analysis and strengthen a feminist perspective, we used Portuguese cinema's History and memoirs. We both avoided mythologising and aimed at unveiling the patriarchal gaze which shapes some literature about Bárbara Virgínia. We built our questioning and analysis from Linda Alcoff's and Teresa de Lauretis's gender studies, from the sociology of culture by Pierre Bourdieu who Bev Skeggs borrowed for her intersection of class, gender and coloniality, alongside historical and social research about both countries' context. The paper focuses on the artistic and familiar roles played by the filmmaker, and proposes an interpretation aimed to contribute to a fine knowledge about gender and class barriers to cultural and professional practices at that time, while it also discusses the erasure of memory about Barbara Virginia.
\end{abstract}

KEYWORDS

Cinema; women directors; the New State regime; Portugal

\begin{abstract}
Resumo
Bárbara Virgínia foi uma das primeiras realizadoras de cinema em Portugal e no Festival de Cannes. Iniciando-se artisticamente como declamadora e atriz, dirigiu, muito jovem, uma longa metragem e um documentário em 1946. Imigrou em 1952 para o Brasil para trabalhar em rádio e televisão. Aí se radicou, constituiu família, abandonando a declamação, e faleceu em 2015. Neste artigo recolhemos e analisamos documentação pública e de memória privada, uma entrevista de investigação e conversas com familiares. Recorremos à história e memórias do cinema português para produzir, de um ponto de vista feminista, uma análise sócio-biográfica. Recusando a mitificação, pretendemos contribuir para a desocultação do olhar patriarcal na literatura produzida sobre esta figura. Os estudos de género de Linda Alcoff e Teresa de Lauretis, a sociologia da cultura de Pierre Bourdieu que Bev Skeggs convoca num cruzamento entre classe, género e colonialidade, e ainda investigação histórica e social sobre os contextos dos dois países alimentaram este questionamento e análise. A sócio-biografia apresentada enfoca-se nos papéis artístico e familiar de Bárbara Virgínia, pretendendo alimentar o conhecimento fino sobre barreiras de género e classe em torno das práticas culturais e profissionais na época e ainda discutir o apagamento da memória sobre a realizadora.
\end{abstract}

Palavras-chave

Cinema; mulheres realizadoras; Estado Novo; Portugal 


\section{A PHOTOGRAPH, A STARTING POINT}

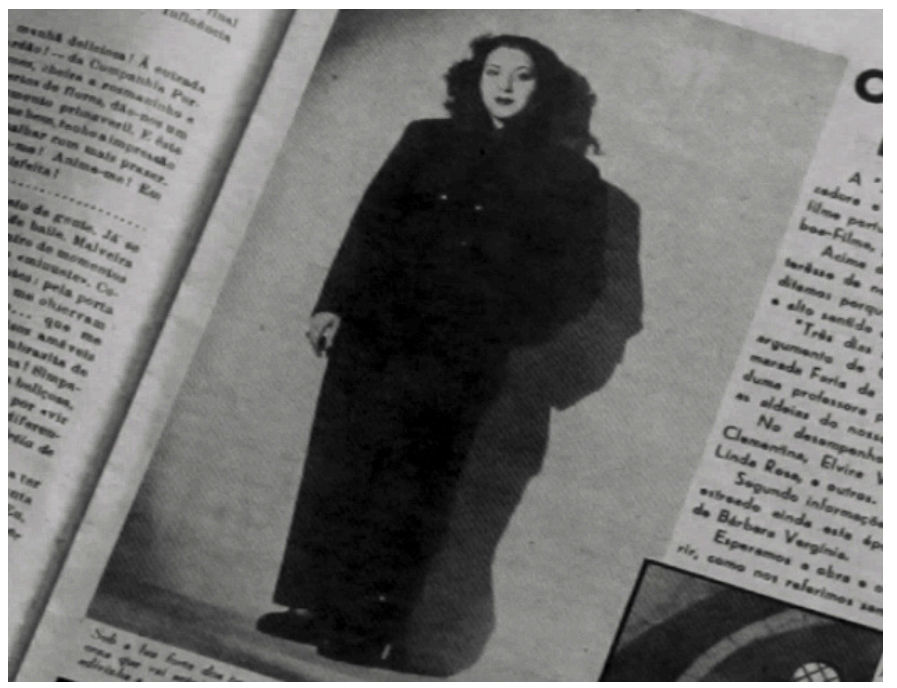

Figure 1: Bárbara Virgínia at the studios of Invicta Filmes Independente, printed with the article O Filme da "simpatia"

Source: O filme da "simpatia", 1946, p. 5

Leaning against a studio wall, wearing a men's suit, a 23-year-old Bárbara Virgínia gazes at us head-on, confident, at ease, unsmiling, as if she had been casually photographed (O filme da "simpatia", 1946, p. 5) (Figure 1). The bold garment, practical for wintertime in that precarious studio, denotes professionalism and appeals to public respect. In other photos, the presentation would be different (Bárbara Virgínia realizadora do filme "Três dias sem Deus", 1948, cover; Pinto, 1951, p.12; Ribeiro, 1983, p. 543).

She would direct her feature film, Três dias sem Deus. It was 1946, and boldness suited the first female director of a feature film in Portugal, and one of the first internationally (Cunha, 2000). That same year, she also made a peculiar short film, Aldeia dos rapazes: Orfanato Sta. Isabel de Albarraque.

Três dias sem Deus would be shown at the first Cannes Film Festival in 1946 (Sarmento, 1946, p. 5), marking the presence of the only solo female director of a feature film' (see the section Sélection officielle 1946: en Compétition in the Festival de Cannes website $^{2}$ ). Bárbara credits Leitão de Barros with encouraging her to compete, who was himself competing with Camões, a nationalist epic film following the line of fascist propaganda of the SNI (National Secretariat of Information) ${ }^{3}$, which gave it multiple awards (Ribeiro, 2010, p. 25; Vieira, 2015, pp. 59-60).

Roughly forty years later, during an interview in Brazil, Bárbara would declare to Leonor Xavier: "I was always emancipated, at 15 I was already a feminist, I think we have the same rights as men" (1987, p. 18). Rich in information, the work contains, in comparison with other sources, divergences that presented us with interpretive challenges,

\footnotetext{
'At the same Festival, another feature film of female authorship was presented, De røde enge (The Red Meadows). Bodil Ipsen co-directed the film with Lau Lauritzen. Both were from Denmark.

${ }^{2}$ Retrieved from http://www.festival-cannes.fr/fr/archives/1946/inCompetition.html

3 The SNI, created in 1944, succeeded the SPN, Secretariat for National Propaganda, established in 1933.
} 
which are very frequent in biographical construction and were a defining aspect of this investigative process.

Born into a middle-class family to a housewife mother and a Navy officer father who participated in the $5^{\text {th }}$ October $^{4}$, Bárbara Virgínia developed a diverse body of art that was replete with contradictions. On the one hand, she was precocious on the stage and in radio and bold in tackling gender roles in both her professional and private life. She later created innovative impressions within cinematography, attempting to explore the surprising side of unusual daily routines. On the other hand, she followed scripts and ideologies of luso traditionalism, with a few traces of colonialist and conservative sexual/ reproductive morals. It is known that these traits were not exclusive to the fascist ideology, and were also assumed by sectors of the so-called Republican opposition. During a more mature phase, she wrote condensed books of etiquette for middle class women. With her new family being constituted within a comfortable social circle in São Paulo, she left her artistic life behind her.

The family memory notes that, in recent decades, Bárbara Virgínia destroyed a significant portion of the photographs and papers from that time, probably due to a certain bitterness in remembering it. The only copy of Três dias sem Deus in Portugal is very deteriorated. We could not locate another copy in Brazil, which had supposedly received one. Of the first 102 minutes, only 22 minutes of film remain in a fragmented and speechless format. Dual erasure: by time, translated in decomposition; by curatorship, in omission from preservation. The soundtrack, performed on the piano by the director, was thus erased as well (Sarmento, 1946, p. 5).

We begin our exploration with that strongly symbolic photo. We pass, emotionally, through the frustration of finding so little about someone who would have filled audiences, generated media attention, marked the forefront of time lines, and elicited admiration or rejection within artistic and intellectual circles. We set out to tackle difficulties, voids and deletions as points of departure for lines of inquiry and to align reflections that, critically, are part of and feed this narrative.

\section{FRAMED BY THEORY}

The intersection of the study of culture, gender and history stimulate our questioning of voids and tensions within a common hermeneutic terrain.

In this case study we relate, very particularly, the approaches of Linda Alcoff (1994, 2005) to gender, identity construction and identity politics, in addition to the relationships between culture, power and feminism. Regarding the biographical portion, we seek to highlight the concept of subjectivity embraced by Alcoff $(1994,2005)$, building on Teresa de Lauretis' problematization (1984). Thus, we do not seek threads of formal coherence, a supposed guarantee of veracity. Subjectivity has been questioned as a fluid,

\footnotetext{
${ }_{4}^{4}$ According to data at the Navy Central Library - Historical Archive, he was a Navy War officer, he suffered an incident in service just before 5 October 1910, dying as a war invalid in 1945; he heeded the call to join the Republican revolt forces; he would be decorated for services provided in S. Vicente, Cape Verde in 1919, after which he retired.
} 
dynamic, historically-situated and socially-constructed reality, "open to alteration by the practice of self-analysis" (Alcoff, 1988, p. 425), in a process of political interpretation and an action-taking orientation. We gather the inconsistencies between episodes or thirdparty narratives, rejecting any mythical veracity. Nor do we approach subjectivity as the opposition between a person's interiority and exteriority.

On the contrary, it is the effect of that interaction - which I call experience; and thus it is produced not by external ideas, values, or material causes, but by one's personal, subjective, engagement in the practices, discourses, and institutions that lend significance (value, meaning, and affect) to the events of the world. (de Lauretis, 1984, p. 159)

Molded by relative positionality in the social context, identity is marked by class, race, gender and the historical power relations that weave the fabric of that context. In turn, and within the possible margins for maneuver, the subjective position is built upon lived experiences. We conceive the subject of our analysis relationally, within a theoretical framework where gender is an important analytical dimension, as well as a place to build and interpret meanings in addition to expressing power and political action.

The individual agency of Bárbara and the social groups she belonged to, the processes by which she ambivalently invested in femininity (Skeggs, 1997) or displayed her dispositions of a cultured person (Bourdieu, 1979), and her entry into the professionalism of a little-industrialized film sector and developing professional field were all held in consideration within a configuration where gender and class are notorious dimensions present in the Portuguese nationalist-colonialist context (Ribeiro, 2010).

We attend to the historic moment of this unique story. Bárbara's initiation into the field of cinematography, first as an actress and later as a director, took place at a time when production remained under the ideological and financial control of Salazar's Estado Novo (New State). That was the role of the Film Section of the Secretariat for National Propaganda (SPN), created in 1933, later reorganized as the SNI (National Secretariat of Information, Popular Culture and Tourism), both directed by António Ferro until 1949.

Ferro's initial political project - the "Politics of the Spirit" - put art, culture and some folklorized entertainment (a so-called popular culture) at the service of propaganda for the regime. Aesthetic, moral and political changes converged in a nationalist body of art, prescribing an "impeccable façade of good taste" that would stem especially from the "spiritual needs of the working classes" (Ferro quoted in Ribeiro, 2010, p. 3940). An "aestheticization of politics" (Ó quoted in Ribeiro, 2010, p. 39) must advance in the symbolic domain.

The discipline of taste became associated with protectionism for a production that, not being very recent, lacked an industrial dimension. The introduction of quotas in 1927 for showing national films led to the emergence of shorts - which would be exhibited before the foreign feature films - although they were not considered to have any artistic value by the institutional guardians of taste. The difficulties of the sector at the level of technology and training artists and technicians led film makers, journalists and critics 
- accumulated facets within a small circle of men - to put political pressure on the state. They called for official support to produce films, namely by way of a studio qualified to make sound films (Ribeiro, 1983). However, film exports remained unsuccessful (Ramos, 2012).

It would only be after the regime fell that another woman, Margarida Cordeiro, would direct, with António Reis, a feature-length film. It was only after the 1980s that female directorship, while still exceptional, would become a reality $(14 \%$ in the last three decades) (Pereira, 2013, p. 107).

This is the briefly-composed frame within which we conduct our socio-biographical analysis of the female director, artist.

\section{BeCOMING BÁRbARA Virginia}

Bárbara attended the National Conservatory in Lisbon (Ramos, 2012, p. 453), studying intensely between 1940 and $1943^{5}$, according to Gentil Marques, who signed as $R e$ porter Two (Repórter Dois, 1944, p. 11) ${ }^{6}$. There, she "took courses in Dance, Singing, Piano and Theater", studying theatre under Alves da Cunha (Ribeiro, 1983, p. 544) and piano under Pedro de Freitas Branco (Xavier, 1987, p.18).

In that interview, she publicly presents herself as having been invested with substantial cultural and social capital by her female predecessors (mother and grandmother) (Bourdieu, 1979). She mentions the circle of artistic and cultural relationships of her family of origin - including Júlio Dantas and the master Rey Colaço - and frequent travels during her childhood (Xavier, 1987, p. 18). Later, we will discuss the networks that she herself would go on to create.

It is, however, by her own choice, and not custom, that Maria de Lourdes Dias Costa (1923-2015) - her legal name - adopts the given names of her mother, grandmother and great-grandmother, which she would pass on to her daughter. She would use Bárbara Virgínia as her emerging adolescent persona and her artistic name, after being fiercely confronted by members on the paternal side of her family. These, unlike her mother and father, reproached her public exposure as improper for a young girl of her social standing (Repórter Dois, 1944, p. 11). This is probably her most persistent tactic of resistance against an oppressive system (Alcoff 1994; 2005), associating self-naming and positionality: she renames herself as an active subject, in opposition to the expectations for her gender performativity; in the critical process of building a biography, her positionality becomes public as she redefines her familial lineage according to the one she identifies with (de Lauretis, 1984).

Known since adolescence as a diseuse, promoted by João Villaret, she was the voice of the Emissora Nacional (Portuguese national broadcaster) (Sarmento, 1946, $15^{\text {th }}$ September, p. 5) in that capacity and as a lyrical singer. She became a theatre and film artist at the beginning of her adult life (Xavier, 1987, p. 18; Matos, 2000, pp. 74-86).

\footnotetext{
${ }^{5}$ Dates confirmed by the academic files of de Bárbara Virgínia at the Conservatório Nacional, 1940-1943.

${ }^{6}$ According to a note written by Bárbara Virgínia in her clipping of that periodical.
} 
Through studio photos and the qualifier of "pleasantness" used in the newspapers (Pinto, 1951, p. 12; O filme da "simpatia", 1946, p. 5; Bárbara Virgínia realizadora do filme "Três dias sem Deus", 1948; Ribeiro, 1983, p. 543), we understand that Bárbara managed her image between the borders of the prevailing sexual morality of her social group and those of artistic and private boldness, garnering both respect and admonition. These were the performance arrangements, resulting from the individual and social negotiations of middle class women, that would synthesize in the glamour of presentation the subjective expressions of femininity, desirability and respectability (Skeggs, 1997).

She ultimately leaves to work in Brazil in 1952, her first contract being with Tupi TV and Radio and, according to her, an invitation from Saladini, a Brazilian cultural attaché in Portugal (Xavier, 1987, p. 18; Pereira, 2016). After six years, she leaves to travel through Angola and Mozambique. She settles in Brazil and builds a family: she marries at nearly 40 years old and is a mother at 52. For most of that time, she lives in São Paulo, where she dies on March 7th, 2015, at $92^{7}$.

Her emigration to Brazil reflected, above all, a hope of liberation from the constraints she experienced in Portugal, without support for film projects and without a positive connection to the rest of her family. Her mother, a widow since $1945^{8}$ and to whom she was very close, accompanied her to Brazil and remained there as her favorite artistic advisor (Figure 2).

Her baptismal name was abandoned even in her private life and ignored in almost all her relationships, whereas her professional name was later registered by Brazil's immigration offices.

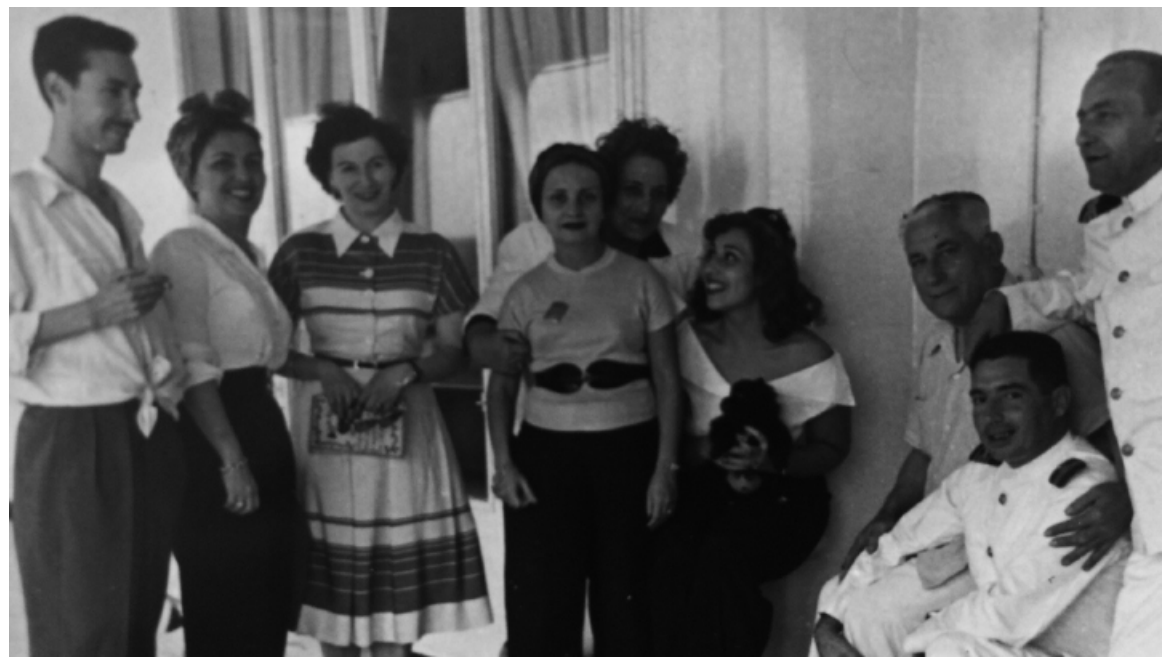

Figure 2: Bárbara and her mother aboard the Vera Cruz, destined for Brazil

\footnotetext{
7 Not on the 8th, as reported by the Portuguese press. See the article "Morreu a primeira realizadora portuguesa de cinema" (Morreu a primeira realizadora portuguesa de cinema, 2015).

${ }^{8}$ See note 4; he died in 1945 (archives of the Navy and the Seventh Civil Registry Office of Lisbon) and not when Bárbara was 11 years old, as published by Leonor Xavier.

9 Migration documents of Maria de Lourdes Dias Costa, 1955; certificate 1984302, registry 457341, Public Archive of the State of São Paulo.
} 


\section{FROM THE IMPOSSIBLE INTERVIEW TO MEETING THROUGH DOCUMENTS}

Bárbara died four days before the co-author of this article, Luísa Sequeira, arrived in São Paulo to interview her. Tracking Bárbara down was a task that had begun months before. The personal proximity, now made physically impossible, would have to be gleaned from her papers, donated by her daughter. They consisted of newspaper clippings, perhaps destined for a scrapbook, and various photographs of herself, etiquette books she had written and emigration service registries. In addition, we were given clippings from a Brazilian fan who preferred to remain anonymous.

Important pieces that we added to this collection were Anto (Vianna and Muller, 1950) - a film script rejected by the SNI - and the Wiliam Pianco and Ana Catarina Pereira interview, the last live recording of Bárbara, at 89 years old. We also analyzed her two films and related documentation deposited in the Portuguese Cinematheque (ANIM, Photographic Library and Archive), as well as various recordings about her family.

Even before the rejection of Anto, she was hurt by the fact that she was passed over for the filming of a documentary, which she had allegedly conceptualized and proposed, as stated in recent declarations. Thanks to the unusual snowfall in Lisbon in 1945, the idea came to her while she was acting in the film Sonho de Amor (Porfírio, 1945). Note that Carlos Porfírio, known as a painter, ethnographer and editor of the only edition of the magazine Portugal Futurista (Ramos, 2012, p. 316; Marreiros, 2001, pp. 423-424), would make another film with a script by Gentil Marques, who would, as mentioned, later cross paths with Bárbara Virgínia.

Bárbara explained her interest in the unusual events of daily life in this way:

I never think I don't have money, but today I thought: I don't have money to direct a documentary. I would like to make a documentary about snow in Lisbon, and they said: What interest does snow in Lisbon have for a documentary? It does have interest, we've never seen it before. It did matter... it mattered! It was a novelty... so someone listened and made "Neve em Lisboa" [Snow in Lisbon], they made it with a different look than I would have done at the time, but he invited me, he was very correct and invited me to present, I had never presented before, I went as a speaker... ${ }^{10}$

She was, therefore, just the voice-over in Raul Faria da Fonseca's film - also now without sound.

\section{BÁRBARA ViRgÍNIA'S WRITING}

She published articles in Modas e Bordados and was an author and editor for Flama and Século Ilustrado (Xavier, 1987, p. 18). We decided not to search for those publications, given the known absence of analytical references for that type of documentation and for the relevance we wanted to give to her cinematography. We did pay attention to the books she wrote.

\footnotetext{
10 Unpublished recording of an interview with Bárbara Virgínia, held by William Pianco and Ana Catarina Pereira, in 2015.
} 
Between 1970 and 1990, while in Brazil, Bárbara Virgínia wrote four etiquette manuals on female roles, directed variously towards women, "executives" and teenagers. Her publishers, Paulinas and Loyola, belonged to ideologically-influential Catholic circles (Hallewell, 2005, pp. 707-708). In them, she mobilizes words and images to advocate for the moral and civic betterment of middle-class families that included capital owners or managers. Mothers were expected to act in an exemplary manner and, through their family influence, mitigate labor and social issues.

\section{FIRST FEATURE FILM: THE BOLDNESS AND THE CONFLICTS}

Bárbara's name will be remembered as the author of Três dias sem Deus (Three Days without God), premiering in 1946. Of relevance, at that time, was the divergence between the ambitious political project of a national cinematographic industry and its effective result in a "decade that would give Portuguese cinema forty-five new films and very little cinema" (Alves Costa quoted in Ribeiro, 2010, p. 29). The project was furthermore meant to supersede the popular but lowbrow genres that attracted large audiences, typically comedy films and vaudeville.

We begin by highlighting the intentionality of the film, which has not been considered until now. The title is based on the Catholic reference to the period of three days between the death and resurrection of Christ, delivering the Earth to itself, without God. Analogously, the doctor and the priest are absent for three days, delivering the village to superstition and uncontrolled irrationality. We will return to the relevance of religiosity, which is carried through the entire film, later.

Raul Faria da Fonseca, for whom she was passed over in directing Neve em Lisboa in 1945, planned the filming of Três dias sem Deus (Bárbara Virgínia, 1946). The script was a product of the text Mundo Perdido... by Gentil Marques ${ }^{11}$ - apparently unpublished, as it is not available in any Portuguese library. Gentil Marques produced documentaries and an extensive body of literature, including novels based on the plots of films he had seen. What we know of is a "Dialogued sequence, a basis for planning", deposited in the Cinematheque with the mention "Inspired by the novel" of his. The dialogues were by Fernando Teixeira, the producer was Invicta Filmes Independente of Lisbon and the distributor was Ibéria Filmes (Três dias sem deus, 1946, p. 6). With filming beginning in February 1946 at the Cinelândia studios, the film would be shown in public six months late.

Regarding professional skills, it seems very likely to us that Bárbara Virgínia would have learned the métier of filmmaking while acting under the direction of Porfírio, who was trained in Paris, where he had lived for a few years in addition to Rome (Marreiros, 2001).

Três dias sem Deus premiered in Lisbon on August 3oth, 1946 at the Teatro Ginásio ${ }^{12}$, receiving generally favorable reviews by the national and local press ${ }^{13}$ (Lourenço, 1946, p.

\footnotetext{
"Currently cited thusly, he would sometimes use the surname Esteveira in his literary name.

${ }^{12}$ And not in 1945, as reported by Félix Ribeiro (1983).

${ }^{13}$ Some of the newspaper clippings in our possession have not yet been fully identified, and we cite here only the most complete reference.
} 
8; Três dias sem deus: esta noite no Ginásio, estreia de um novo filme português, 1946, p.9; Visor 42, 1946, p. 5). We located records of its showing in Santarém for two days in November of that year (Moreira, 2013, p. LIV).

We move on to a detailed analysis of the script and its critical reception. We do this given the current state of the film and to highlight relevant aspects that, up until now, have not been considered.

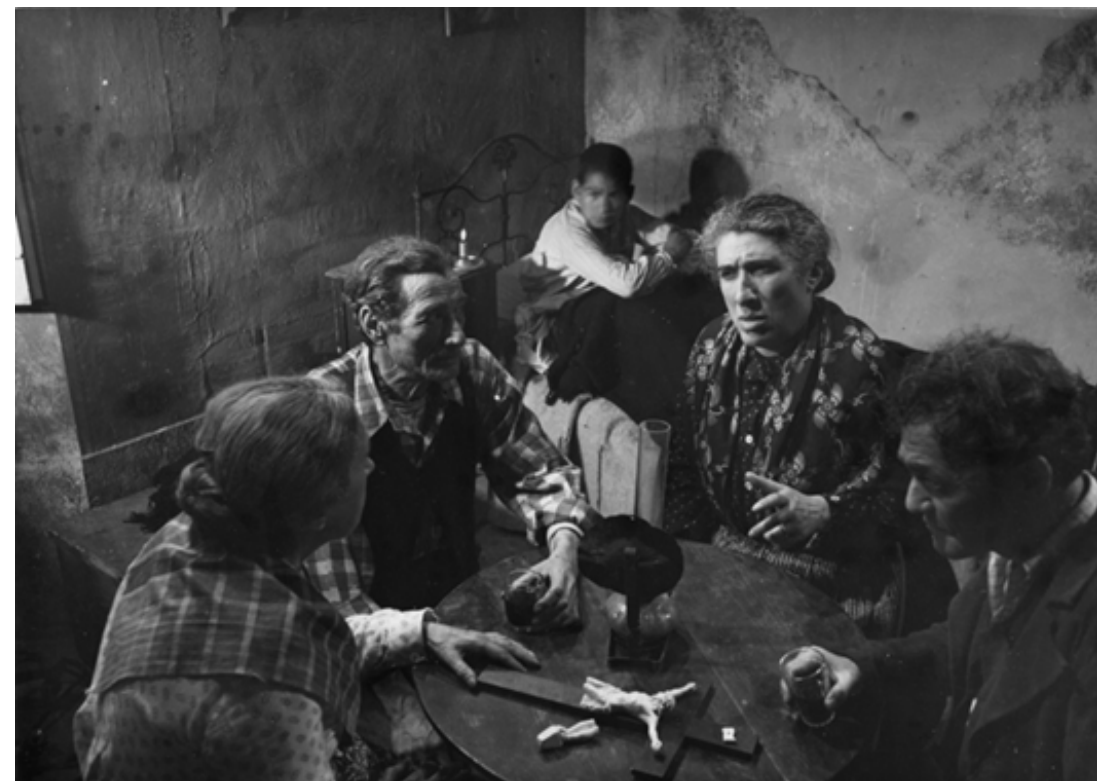

Figure 3: Scene from Três dias sem Deus (Bárbara Virgínia, 1946). Villagers are suspicious of the newcomer teacher and the father of the wealthy family

Source: Collection Cinemateca Portuguesa, Museu do Cinema

The plot centers on a young, caring teacher who has recently arrived at a village - located below - and is not well-received by the poor, rural families due to her big-city attitude (Figure 3). At school, she opposes an old woman's use of a traditional remedy to treat a student, insisting he see a doctor. In the meantime, the priest and the doctor have left the village. Delayed by an unforeseen night-time storm, she takes shelter in the castellated, hilltop home of the highest-class family - above - whose daughter and son she teaches at school. In doing so, she avoids returning to the village and the awaiting, now-open hostility of the villagers, who have forbidden their children to go to class. The events take place from there, and, within the fantastic atmosphere that accumulates, a family drama unfolds alongside the local drama. The mother, long isolated in her room due to mental illness and paralysis, has never again appeared in public. Village rumors attribute her current state to a murder attempt by her husband, even accusing him of causing a fire at the church.

Here we point out that, at the school and with the wealthy family, the teacher embodies the ideal of the caring woman inspired in Catholicism and fed by the political regime (Pimentel, 2011). Aside from contradicting primitive beliefs, she demonstrated morally-guided diligence in the face of the father's emotional distance from his children 
and wife, the latter rendered to the care of her personal maid. The figure of the father is not far removed from the cinematic Estado Novo cliché of the Republican beaten by the new regime: an educated, wealthy man, distanced from the people, a non-mass-attender. The mother is a doubly stigmatized character: the uncontrolled arts embodied in her dementia; the source of evil embodied in her gender. Her atonement for her family will break with the final climax of the film, when the village realizes the true reason for her state.

That night, a mob of villagers gathers to break into and burn down the castle, under the accusation that the owners are possessed by the devil. Shortly before this, however, tension emerges between the teacher and the man of the house. According to the "dialogue sequence", the father insists she move into the home to care for his needy son. Upon her refusal, he admits his desire for her: "it is I... it is I the one who needs you, your youth", receiving a response of "no, let me be. Please, let me be...". During the invasion, the irrational, torch-wielding mob, a cliché of the popular movements that took place during the Republic, is shocked to find the family gathered to pray at the initiative of the teacher. They are even more shocked to find the wife recovered, through psychological reversion before the very flames they carried.

It is the teacher who, providentially, suppresses the vigilante ire and restores order. However, despite being cultured and devoted, she lacks legitimacy in the eyes of the village. Normalcy in the school will be restored following the return of the doctor and the priest, the subordinating moral and patriarchal authorities (Figure 4).

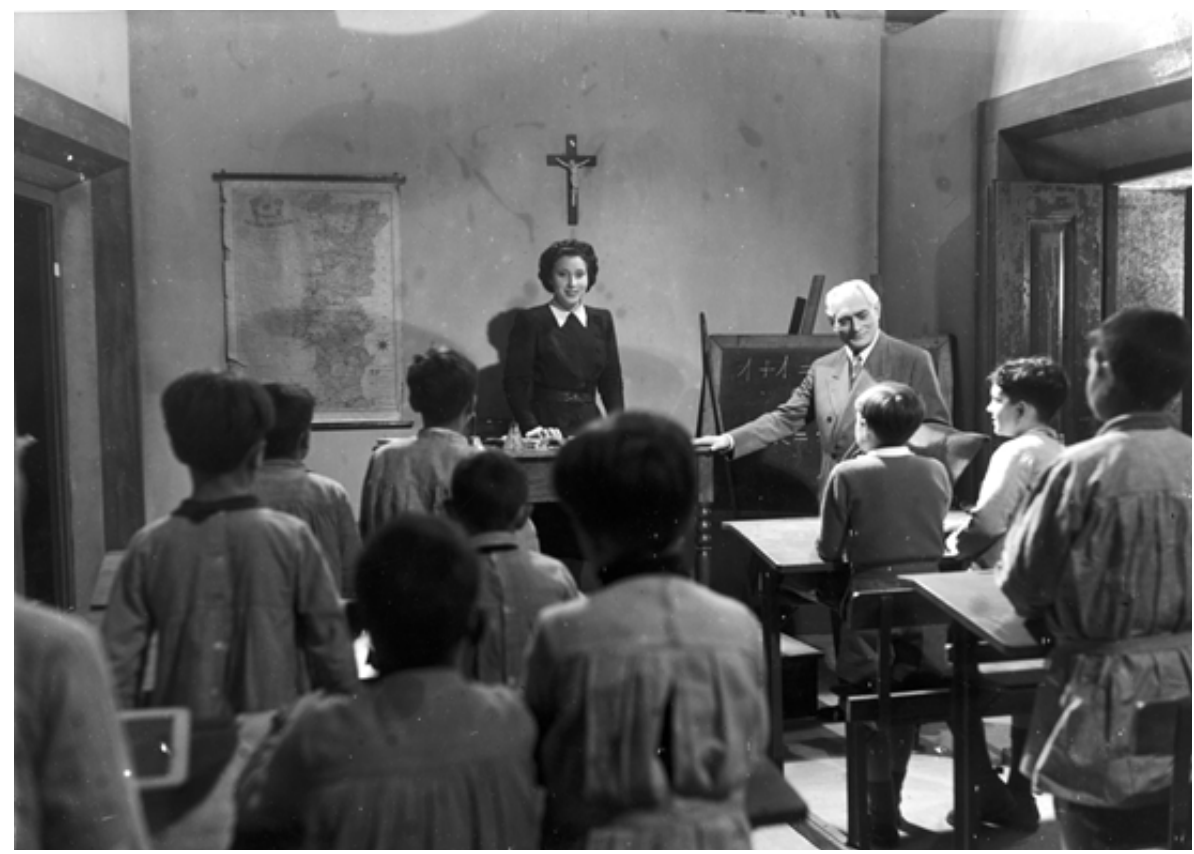

Figure 4: Scene from Três dias sem Deus (Bárbara Virgínia, 1946). The school Source: Collection Cinemateca Portuguesa, Museu do Cinema

From what remains of the film, in line with Marisa Vieira (2009) and, earlier, Félix Ribeiro (1983), we can see that Bárbara Virgínia created a dark environment between 
dream and reality, both in the scenography and in the natural locations. She built suspense, intensifying the drama of the acting with high-contrast black-and-white images, with depth of field, deep shadows and backlighting. Using close shots, she created psychological profiles of the characters, haunted by ghosts and ensconced in fears.

As defining traits of this narrative, we call attention to a few analogies with films that were ideologically-aligned with the regime. Following Patrícia Vieira (2005) and Carla Ribeiro (2010), we maintain that readings of the works of this period lack an approach of the symbolism of plots, characters and scene and portrait compositions, and that these, more than individuals or social groups, provide us above all with stereotypes. We also do it particularly to highlight the dissonances present in Bárbara Virgínia's work. Such is the case in her view of the place of exclusion and the social types of a dark, backward rurality, symbolically located below, crudely displaying, however, the poverty associated with ignorance. The teacher, who accesses and connects with the privileged place above, exerts herself and perseveres in the hopes of making a change through education and social conciliation, ideas with Republican reverberations.

The location of privilege, the castellated home of the property-owning family, coinhabited by maids and servants, is equally dark, devoid of emotions, with intense points of light focused on faces, especially that of the teacher. If it is not an urban space, in the traditionalist dichotomy of country-purity versus city-perdition, it is equally penalized. It will be rocked by the irrational vengeance of the poor, overcome only by the measured fire of the candles and prayer, which pacify and unify the two groups.

\section{Advertising ANd ReCeption Of TRÊS DIAS SEM DeUS}

Given this analysis, it would be believed that the work would have all the ingredients to be well-received by the closed and conservative sectors of Portuguese society. Many articles were written, some underscoring the good audience turnout (Lourenço, 1946, p. 8; Sylvan, 1946, pp. 22-23; Visor 42, 1946, p. 5; Três dias sem deus: esta noite no Ginásio, estreia de um novo filme português, 1946, p.9).

However, aesthetically and politically - we refer to the broad spectrum of power relations that involve cultural production, the practices of artistic achievement, and the ideas that are received, shaped and disseminated in the process - there was an expression of different opinions, some even outright divergent. We begin with the publicity.

Anticipating the premiere, two different-sized announcements elicited different readings: first, religious respect for the cross, outlined in black with the publicity text written inside; second, national pride for a "100\% Portuguese" film, mentioned in the subtitle, during a post-war period that was notorious in other pages of these newspapers; and third, the appeal to fun aroused by a brainteaser with a prize for its solution. In a publicity stunt, the distribution company challenged the readers' intelligence, giving away the solution: serious, but not for intellectuals, was the subtextual key (Três dias sem deus: filme 100\% português dirigido por Bárbara Virgínia, 1946b, p. 9; Três dias sem deus: filme 100\% português dirigido por Bárbara Virgínia, 1946a, p. 3). We could 
not determine what to attribute the devotional character of the publicity to; we only know that the only financial backer of the film was a merchant from Lisbon, a silent partner and financier of Invicta Filmes Independente ${ }^{14}$ (Ribeiro, 1983, p. 544). We also located vignettes advertising the film $\mathrm{m}^{15}$, using the image from the publicity flyers, apparently destined for postal usage (Figure 7). The logotype appears to read, "Tradition". This practice recalls memories of fundraising campaigns for Catholic missions in the colonies, still taking place during the middle of the last century. Another advertisement was placed in announcements of current graphic composition (Um novo êxito do cinema português: Três dias sem Deus, 1946, p. 3).

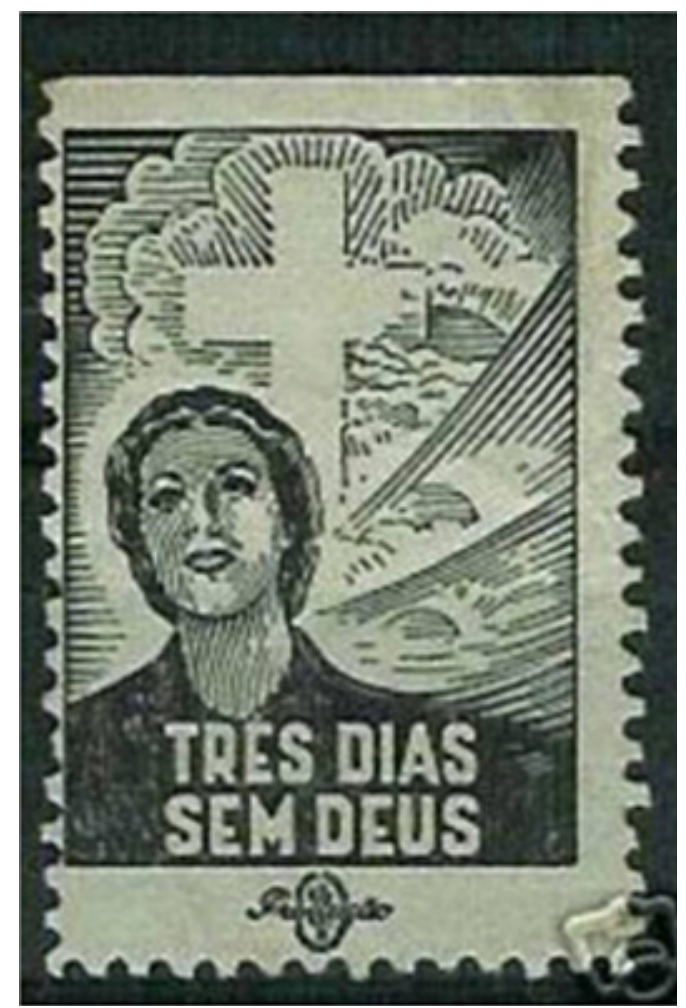

Figure 5: Vignette recalling the movie Três dias sem Deus in a stamp format Source: https://www.delcampe.net/fr/collections/item/45580603.html

All the known film figures of the time, directors and the regime's prescribers of cinematic canon, were present at the premiere: António Lopes Ribeiro and Chianca de Garcia, who were newspaper film critics as well, Leitão de Barros and Brum do Canto. The big names of the small aforementioned circle were united by academic training in the arts and a will to push forward a new cinema for the "New State". They wanted to abandon the old productions that, they alleged, did not follow the cultivated taste nor the technical mastery of the SPN's tutelary body of cinema, which they were a part of (Ribeiro, 2010, pp. 20-21).

\footnotetext{
${ }^{14}$ It was Felisberto Felismino, known as the representative of a brand of permanent ink pens.

${ }^{15}$ Found on Delcampe Net webpage with mention of being a vignette with a perforation error. Retrieved from https://www. delcampe.net/fr/collections/item/45580603.html
} 
Of these critiques, we first present a disapproving view, to be followed by others taking on a different tone.

The journalist António Lourenço $(1946$, p. 8) details his evaluations in the morning paper $O$ Século immediately following the premiere ${ }^{16}$. He praises the novice work, with "different forms of expressionism." He notes as a virtue "the primacy of the image: expression and movement with a minimum of words", the refined aesthetic that is a departure from the campy films, "using new styles of production." He disapproves of Bárbara combining directing with acting and admonishes her. In terms of the plot, he mentions the "profile of a somber human aggregate," where the "characters [are] hunched under the weight of a tragedy." Both the superstitions and the "absurd beliefs" of those "good but brutish people" provided, in his opinion, "magnificent elements of inspiration," for a "first case of psychological depth in Portuguese cinema." He thus implies that Bárbara missed that opportunity because, allegedly, she changed the original intent of Gentil Marques, who was absent during filming. The fact that it was a controversial issue is clear from the Esclarecimento [Clarification] (Esclarecimento, 1946, p. 9) next to the aforementioned advertisement with the cross in Diário Popular. It clarifies that Raul Faria da Fonseca is responsible for the cinematic sequence, not for the modification introduced ${ }^{17}$. It should be noted that we diverge in our interpretation of the text from Lisboa (2016, p. 52) that quotes Fonseca as the author and not Marques, we believe supported by reference to the fact that Bárbara was called in to substitute that experienced director. Again, and returning to Lourenço's (1946, p. 8) article, the result of the director's decision was that, despite the richness of the plot and the "richness of the character and objectivity of effects" provided by Fonseca, the "characteristics of some characters and the meaning of their reactions" were distorted. "A blatant example" lies in the fact that the protagonist, "due to a lack of psychological definition", left the public with doubts about whether her actions were meant to condemn the superstitions, "as a reflection of her duties as a teacher or as a pronouncement of her love for the boy's father". Lourenço does not only disagree, he states: to face the man "who all despise", it was necessary to have "a teacher figure with the moral greatness of a symbol that might personify, sometimes our conscience, and other times, the guardian angel or a heart illuminated by the most beautiful feelings of tenderness and Christianity, which Providence might cast upon that hamlet to make the boy's father happy and lead to the regret of all those who booed him." And he proposes: "the mask should define, with the greatest clarity, the torments in which her spirit debated". Even if the archived dialogue is known and there is a record of various notes with alterations, the images and sound of that contested sequence did not reach our days. We can, however, understand that her fault resulted from of a lack of ostensibly embodied refusal, given that, according to the script, she would have responded: "let me

\footnotetext{
${ }^{16}$ Lourenço collaborated also with the Movimento and Mundo Gráfico periodicals (see Mangorrinha 2014).

17 "For all due effects, it is clarified that in the publicity for the film 'Três dias sem Deus', it was not mentioned that the initial planning of the film was later altered without intervention by the author, who was absent, with all responsibilities for the script (cinematic sequence) falling upon Raul Faria da Fonseca, in that which the script was not prejudiced by those circumstances" (Esclarecimento, 1946, p. 9).
} 
be, let me be". The contracted facial expression of the teacher, however, allows us to read her rejection.

Smaller flaws, such as connections between scenes or of lighting, did not get in the way of the approval and enthusiastic applause of the audience, he notes in conclusion. However, in "Final Note", he warns: of the film that will represent the country in Cannes, "breaking new horizons in Portuguese cinema," he hopes that it will reveal "other human landscapes and other scenes of Portugal - but with sense and prudence!"18 (emphasis added by the authors). The nationalist sense feared portraying a raw image of poverty and backwardness to the outside world. Patriarchal vigilance, in its turn, which demanded a strong condemnation against the advance of the father, was disproportionate and resulted in an ostensive public rebuke.

The critic invested himself with moral authority in the face of a problematic performance before an international competition due to its non-compliance with the standard of the edifying and model narrative. If Bárbara the actress was in need of repair, it was Bárbara the director who was condemned and admonished. The reprimand does not seem to be the result of an accumulation of roles in a single production, but rather the entry of a woman in a freshly-constituted professional field of a male carving, alluding to her fragility and inexperience. We recall that women of status were only expected to perform reproductive work and to abdicate from productive work (Salazar quoted in Vieira 2015, p. 173).

By taking on the creative role with the most decision-making power, the young director embodied an affront to gender conformity within the field of film, and not just. In those years, the growth of the number of salaried women would cease, and aspects of their conditions as workers and citizens would worsen. Positive changes in that area would only take place much later, in the 1960s (Pimentel, 2011, pp. 74-81).

In sum, although he minimized the technical faults, as did other critics, Lourenço condemns the director/actress for not making herself responsible for the conscience of the father of the family. And within the patriarchal logic, in the face of his transgression, she is the one exposed for public condemnation.

This detour of Bárbara's would have built up with sanctionable positions in the historical and social context of her twenty years of age, which would come to shape the way she would evaluate censorship regarding her work, as we will see.

We now highlight the divergent perspective and diverse reading of two other critics, one demonstrating a more advanced aesthetic sensibility, both praising the presence of a woman behind the cameras. Visor 42 (1946, p. 5) considered Três dias sem Deus a "serious film of high dramatic romanticism". He only lamented that it was "excessive in effects," aesthetically reproaching the "different forms of expressionism" that Lourenço had appreciated. He notes with pleasure the capacity to "evidently create a piteous, even horrific, atmosphere, above all one of constant emotional unrest", associating it with

\footnotetext{
${ }^{18}$ In contrast with these human landscapes, a euphemism for the village of poor and ignorant people portrayed in Três dias sem Deus, Leitão de Barros, in a fit of national pride, declared in an article in Mundo Gráfico, "What is the most beautiful place in Lisbon?" "I will not answer. This is not even a question you can ask a 'Friend of Lisbon'! Lisbon (...) does not have ugly places," (see Mangorrinha, 2014).
} 
Rebecca and Wuthering Heights, which provided "the same stirring feeling of suspense and horror." He reminds us that Bárbara Virgínia "had said, and rightfully so, that she wanted to make a rustic tragedy, and it is from that angle that her work should be analyzed." Implicitly referring to Lourenço's critique on the morning of the same day, he refuses to comment on whether or not "the exteriorization" "always" accompanied "the psychological analysis", if the modification in the script improved or worsened the result. He summarizes, confirming his more modern taste: "if in touching upon the sinister we like it less, we must recognize, however, that it remains an imperative dramatic play." Unlike other critics, he declares: "Bárbara Virgínia deserved the flowers that, in the end, fell at her feet, not just because she is a lady, but also because she is an artist, in the broadest sense of the word". "It does not cease to be audacious and pleasant to see a lady working in the national studios as a director!" He praises the performances of the various artists, "in a homogeneous performance adjusted to the intentions of the work", the "photograph of Tony" with "notable paintings", affirming that "the sound, score, scenery, [and] montage [demonstrated] an already advanced technique". We note that Visor 42 was the journalistic pseudonym of Arthur Portela (Ramos 2012, entry Heróis do Mar). Azinhal Abelho, due to the Portuguese representation in Cannes being "made almost [entirely of] men" would, years later, comment emphatically: "had it not been for Bárbara, it would almost seem women were not a part of film in Portugal" (1959, p. 52).

\section{A forgotten documentary: Aldeia dos Rapazes}

According to the records at the Cinemateca Portuguesa, Bárbara Virgínia directed a second film. Aldeia dos rapazes: Orfanato Sta. Isabel de Albarraque [Village of the Boys: Sta. Isabel de Albarraque Orphanage] (1946) is a short film about that specific Catholic institution. Almost unknown to cinematic critique and overlooked in scientific research, it is present in bibliography of reference (Cruz, Ferreira \& Pina 1989). Its poor state of conservation robbed it of its sound, just as the feature film has been. Together with Jogo da Sardinha (Game of the Sardine), it was shown as a prelude to the showings of Três dias sem Deus in Lisbon. Journalists António Lourenço (1946, p. 8) and António Sarmento (1946, p. 5) both refer to it, the first erroneously attributing authorship of Jogo... to Bárbara and the second to José de Oliveira Costa. Visor 42 is concisely approving (1946, p. 5): “they seemed very interesting complements, 'Aildeia [sic] dos Rapazes' and 'O jogo da sardinha"".

What is interesting is understanding how, going against convention and expectation, the narrative focuses on the boys and not the institution. Where we might expect sadness and suffering, we are shown surprising childhood games: some children prepare for a party in the boys' orphanage. They put on makeup, wear dresses and false breasts and act as substitutes for the - inexistent - female dance partners. In another scene, the children are involved in a happy pillow fight. Zéro de conduite, a film by Jean Vigo from 1933, which included a similar pillow fight, had long been censored in Portugal and France, making it unlikely that Bárbara had seen it. 
In this short, the director adopts original perspectives and demonstrates technical mastery: occasionally, there are boys who intimately look directly at the lens; in the final images, a bucket of water is thrown at the camera during play. The general tone is one of benevolently-portraited childhood fantasy and irreverence.

Also produced by Invicta Filmes Independente in 1946, Aldeia dos Rapazes was filmed in Albarraque, the location of the boys' orphanage and some of the exterior scenes of Três dias... Probably shot quickly and without a script - not archived in the Cinemateca - this documentary was certainly produced in a freer way. There is little reference to its exhibition and none mention it exclusively.

This short film must not be confused with others of the same name, by Adolfo Coelho, produced about institutions for minors in other locations. The 1947 Aldeia dos rapazes da rua [Village of the street boys], about the Casa do Gaiato run by Father Américo, was a film commending that institution and produced by the SNI. It was even shown during catechism classes in the 1960s and, as we recall, was shown on television, with aesthetic characteristics and content that was unlike the work on Albarraque. Regarding existing questions on Bárbara's authorship, those that we have placed are more directed towards the conditions and purposes of the production. In Lisboa's (2016) critical reflection, which questions the attraction of Três dias sem Deus, we diverge, for all the reasons listed here, regarding any possible attribution to Coelho.

\section{Rejection of The Plan for ANTo}

Four years after the Três dias sem Deus experiment, Bárbara Virgínia planned to direct another feature film.

The topic would be António Nobre, her favorite poet and whom she would frequently recite (Neves, 1986, pp. 28-29). Nobre is considered by some critics to be an innovator in writing, a cultivator of symbolism in poetry, favoring nostalgic and traditionalist topics. At the time, he was a bold creator, and his (short) private life was the subject of scrutiny and moral condemnation for his intimacy with other men.

The script (Vianna and Muller, 1950) focuses on the indecision of António (Anto) Nobre in the face of a romantic choice between two women, one rich and one a maid at a república académica ${ }^{19}$, both patient, both determined to tame his (bad) temperament and improve his academic performance. The context invokes all the conventional practices of student life ( $\mathrm{fado}^{20}$, all-nighters, exams) and praxe académica ${ }^{21}$. Pretext was created for scenes of student recitations, with a focus on Nobre, and disputes over literary preferences.

Financing for Anto would be rejected by the SNI in 1950, alleging a lack of funds and coinciding with more oppressive control over cinematic production, part of the National

\footnotetext{
${ }^{19}$ Name given to university student residences managed by the students themselves - similar to a fraternity.

${ }^{20}$ Translator's note: In this case, Fado de Coimbra, a traditionalist style of music typically performed by male students at the University of Coimbra, dressed in black capes and with at least one guitar and one singer.

${ }^{21}$ Translator's note: a sort of "hazing" imposed by older students on first-year university students.
} 
Film Fund (FCN) since 1948, and which was supported by a Film Council controlled through government representatives (Ribeiro, 2010, p. 29).

On the rejection and its impact on her continuing to make films in Portugal, Bárbara would publish decades later: "I was always very independent - and that is why censorship cut me off" (emphasis added by the authors) (Xavier, 1987, p. 18). Curiously, the saved clipping contained handwritten notes surrounding the highlighted expression with question marks. More than censorship, strictly speaking, she must have resented the accumulation of experiences of disapproval and gendered omission, both familial and artistic, that contradicted the figure of an independent and self-sufficient woman that she had created.

As we have mentioned, Bárbara Virgínia's set of ideas shows dissonances that demand reflection. However, we have no doubts as to her commitment to a religiousness with a conservative outlining of a social class that set itself as a moral standard for the whole of society. In the books she wrote, the films she directed and the project that was never completed, it is present in exemplary moral types, in prescriptions of family life. We view as hyperbole, and perhaps intentionally controversial, her declaration on how she yearned to make another film: if, by some stroke of luck, she were able, she would make "a film about Christ - the revolutionary, the socialist, the Man" (Neves, 1986, pp. 28-29).

\section{Trading Portugal for Brazil}

In the interview she gave at 64 years old, Bárbara used blunt language in remembering her departure from Portugal: "I abdicated my name when my family thought that female artists were prostitutes. I am just Bárbara Virgínia and I would not like to talk about the family, who cast me out," (Xavier, 1987, p. 18). However, once in Brazil and after having performed nearly 600 poetry recitations and leading the commemorations of the centennial of Garrett, and being given an award as a result ${ }^{22}$ (Abelho, 1959, p. 52), she abandoned her artistic practices immediately after her marriage so as not to "hurt", in her words, her husband, since "any man who is not in the area has a distrust of the arts" (Xavier, 1987, p. 18). The growing adversity of the Brazilian context would be added to an already heavy load, as we will discuss next.

Bárbara rejected an invitation in 1954 to direct a commemorative film for the quadricentennial of São Paulo upon the advice of her mother, who feared political exploitation (Matos, 2000, pp.74-86). The commemorations were effectively used to also celebrate the anniversary of the 1932 Brazilian constitution and the dictatorial regime of Getúlio Vargas, also known as the Estado Novo.

Bárbara would maintain a network of social and artistic relationships in São Paulo. For this purpose, she gave a substantial contribution towards the opening of a restaurant in the city, Aqui, Portugal [Here, Portugal], a place for meeting with friends and seeing shows, where she would entertain known figures of local power and culture, as well as stars like Edith Piaff, Tony de Matos and Amália Rodrigues (Abelho, 1959, p. 52). Note

\footnotetext{
${ }^{22}$ Judging by the title of the article, the "Castro Alves star" would be a bronze trophy.
} 
that the establishment is named after the film she appeared in in 1947, Aqui, Portugal by Armando Miranda (Cunha, 2000).

In Brazil, despite her activity in radio and television, she would not even participate in a single film. The reception of Portuguese cinema had changed in those years and, by default, of its stars. Heloísa Paulo (2002) notes how, in the 1940s, the efforts of some Portuguese businessmen to connect Portuguese cinema to its emigrants in Brazil would fail. In the decade before, the showing of Portuguese films, supported by newspaper and radio press, had some commercial success. At the time, Brazilian legislation protected national production, and furthermore, the difficulty of Brazilian audiences in understanding the pronunciation and idiomatic expressions of Portugal, compounded by poor audio and the incidental decline in Portuguese production, made the whole project impracticable, as Félix Ribeiro also noted (1983, pp. 557-558). The Portuguese commercial offer was limited to musicals of a regional nature, and repeatedly exhibited. Starting in the 1950s, Brazil would receive a series of Portuguese documentaries with pompous narration and nationalistic themes, glorifying the accomplishments of the Estado Novo. They found a small audience in the emigrants, but were disliked by Brazilians living in large urban areas who resented their trademark fascist propagandism, as well as their aesthetic, technical and cultural inappropriateness (Paulo, 2002, pp. 83-94).

The heaviest weight in deciding to emigrate must have certainly been the difficulty of independently financing herself, to which would have been added the growing censorial and financial restrictions of the SNI itself (Ribeiro, 2010). The lack of alternatives to this system, the gender barriers in filmmaking, the break with her paternal family, everything combined to overshadow the conditions of her remaining in Portugal. Ironically, she did not find much better conditions in Brazil, in the years that followed, in order to fulfill her "great dream" of returning to filmmaking, which she alludes to during the final days of her life.

\section{Concluding}

Bárbara Virgínia was trained as a middle-class woman and a cultured artist, in confrontation with her exclusion by more conservative family members, her self-perceived professional segregation due to her gender and the conservativism and shuttering of cultural life of a society under a fascist regime. Her appreciation of adverse experiences and insertion in artistic social and professional circles provided her with identity performances and narratives and a varied path for constructing public and individual subjectivity. This path was self-perceived from the diverse opportunities she found, in Skeggs' (1997) view, in the markets of cultural resources, economics and marriage.

She ambivalently debated with a morality that reduced her autonomy in the public sphere and placed excessive demands in the private. While the borders between the more publicized public space and the more publicly sought after private space diminished, due to her professional exposure, while the space for surveilled artists to maneuver diminished, the patriarchal and totalitarian demands and scrutiny placed upon her 
life doubled. The latter came to take on, even if unwelcomed, more political edges that she could not shake due to her autonomous and bold positionality.

The analyzed artistic and literary production leads us to consider that, not resulting from a feminist perspective, her cinematography showed boldness, occasionally questioning and stirring up gendered professional and artistic standards. She tested, incipiently, placing focus on details of daily life and social relationships according to a non-dominant vision cultivated by some of her contemporaries, wherein the woman is a spectator of herself and not a mere spectacle (de Lauretis, 1984). Forced to interrupt her path in filmmaking, which she had accessed at great cost and where she long remained alone, we are left only to conjecture as to how her life could have been had she lived under other political and cultural conditions.

In the professional realm, her films have been marked by deterioration, erasure and oblivion, not just materially, but symbolically. Relevant on their own for the marks of gender that they conveyed, these erasures contrast above all with the esteem her feature film and appearances on stage and radio garnered. Inverting the perspective, the deterioration of the image, the muting of the sound, and the neglectful preservation, although not exclusive to her works, underline what perfect copies would more easily dilute: her memory was built and eroded by Bárbara's own active de-selection, but, above all, upon that other adversity of a patriarchal hallmark, even if passive, carried out then and now by institutions, professional and social groups.

\section{BibliogRAPHIC REFERENCES}

Abelho, A. (1959, 31 de janeiro). Bárbara Virgínia em bronze. Festa, p. 52.

Alcoff, L. (1988). Cultural feminism versus post-structuralism: the identy crisis in feminist theory. Signs, 13, 425 .

Alcoff, L. (1994). Cultural feminism versus Post-Structuralism: the identity crisis in feminist theory. In N. Dirks et al. (Eds.), Culture power history: a reader in contemporary social theory (pp. 96-122). Princeton, New Jersey: Princeton University Press.

Alcoff, L. (2005). Visible Identities: Race, Gender, and the Self. Oxford: Oxford University Press.

Bárbara Virgínia realizadora do filme "Três dias sem Deus" (1948, 31 ${ }^{\text {st }}$ August). O Século ilustrado: revista portuguesa da actualidade mundial, 452.

Bourdieu, P. (1979). La distinction: critique sociale du jugement de goût. Paris: Les Éditions de Minuit.

Cruz, J. M.; Ferreira, A. J. \& Pina, L. de (1989). Prontuário do cinema português. Lisbon: Cinemateca Portuguesa.

Cunha, A. (2000). Cineastas portuguesas 1874-1956. Lisboa: Arquivo Municipal de Lisboa. Retrieved http:// videoteca.cm-lisboa.pt/fileadmin/VIDEOTECA/publicacoes/lista/cinema_portugues/cineastas_ portuguesas.pdf

De Lauretis, T. (1984). Alice Doesn't: Feminism, Semiotics, Cinema. Bloomington: Indiana University Press.

Esclarecimento (1946a, 30 ${ }^{\text {th }}$ August). Diário Popular, p. 9. 
Hallewell, L. (2005). O livro no Brasil: sua história. São Paulo: EdUSP.

Lisboa, R. V. (2016). O restauro cinematográfico e a Teoria dos Cineastas: o caso de Bárbara Virgínia. In M. Penafria; E. T. Baggio; A. R. Graça \& D. C. Araujo (eds), Propostas para a teoria do cinema - Teoria dos cineastas - Vol. 2 (pp. 39-69). Covilhã: LabCom.IFP. Retrieved from http://www.labcom-ifp.ubi.pt/ ficheiros/201704191500-201701_teoriacineastasii_mpenafria.pdf.

Lourenço, A. (1946, 317 August). "Três dias sem Deus" de Bárbara Virgínia estreou-se no Ginásio com agrado. O Século, p. 8.

Mangorrinha, Jorge. (2014). Mundo Gráfico 1940-1948 [ficha histórica]. Lisbon: Hemeroteca Digital. Retirado de http://hemerotecadigital.cm-lisboa.pt/FichasHistoricas/MundoGrafico.pdf

Marreiros, G. M. (2001). Carlos Filipe Porfírio. In Quem foi quem?: 200 Algarvios do Século XX (pp. 423-424). Lisbon: Edições Colibri. Retirado de http://republica-sba.webnode.com.pt/products/ carlos-filipe-porfirior/

Matos, H. de (2000, $23^{\text {th }}$ September). A primeira realizadora portuguesa. Revista do Expresso, pp.74-86.

Moreira, M. T. (2013). Todos têm direito à cultura: a dinâmica cultural da cidade de Santarém (1930-1959). Tese de Doutoramento. Universidade Nova de Lisboa, Lisboa, Portugal.

Morreu a primeira realizadora portuguesa de cinema (2015, 12 de março). Jornal de Notícias. Retrieved from http://www.jn.pt/cultura/interior/morreu-a-primeira-realizadora-portuguesa-de-cinema-4450111.html

Neves, J. A. da (1986, 18 de agosto). O teatro podia ser elo entre Portugal e Brasil. Diário Popular, pp. 28-29.

O filme da "simpatia" (1946, abril). Filmagem, za série, 64, p. 5.

Paulo, H. (1994). Estado Novo e propaganda em Portugal e no Brasil: o SPN-SNI e o DIP. Lisboa: Minerva.

Paulo, H. (2002). O emigrante e o cinema: sociabilidade e nacionalismo. Locus - Revista de História, 8(2), 8394. Retrieved from https://locus.uff.emnuvens.com.br/locus/article/view/2462.

Pereira, A. C. (2013). Mulheres por detrás das câmaras: a ficção de longa-metragem, mediada por um olhar feminino. In F. Lopes \& A. C. Pereira (Eds.), Filmes Falados: Cinema em Português, V Jornadas (pp.95108). Covilhã: Livros LabCom. Retrieved from http://www.livroslabcom.ubi.pt/book/10ı\#Abstract

Pereira, A. C. (2016). A Mulher-Cineasta: da arte pela arte a uma estética da diferenciação. Covilhã: LabCom. IFP. Retrieved from http://www.labcom-ifp.ubi.pt/ficheiros/201603081045-201522_mulhercineasta_ acatarinapereira.pdf

Pimentel, I. (2011). A cada um o seu lugar: a política feminina do Estado Novo. Lisbon: Temas e Debates / Círculo de Leitores.

Pinto, R. (1951, 15 ${ }^{\text {th }}$ September). Quando volta Bárbara Virgínia? Plateia, 12, p.12.

Ramos, J. L. (2012). Dicionário do Cinema Português: 1895-1961. Lisbon: Caminho.

Repórter Dois (1944, 30 ${ }^{\text {th }}$ March). A família expulsou-a, porque ela quis ser artista! Vida Mundial, p. 11.

Ribeiro, C. P. (2010). O "Alquimista de sínteses": António Ferro e o cinema português. Dissertação de Mestrado, Universidade do Porto, Porto, Portugal. Retrieved from http://repositorio-aberto.up.pt/ handle/10216/55466

Ribeiro, M. F. (1983). Filmes, figuras e factos da história do cinema português 1896-1949. Lisbon: Cinemateca Portuguesa. 
Sarmento, A. (1946, 15 ${ }^{\text {th }}$ September). Três dias sem Deus da jovem realizadora Bárbara Virgínia. Gazeta do Sul, p. 5.

Skeggs, B. (1997). Formations of class and gender: becoming respectable. London: Sage.

Sylvan, F. (1946, Deeember). Três dias sem Deus. Brisa, 3, pp. 22-23.

Três dias sem deus: esta noite no Ginásio, estreia de um novo filme português (1946, 30 $0^{\text {th }}$ August). Diário Popular, p. 9.

Três dias sem deus: filme 100\% português dirigido por Bárbara Virgínia (1946a, 30 ${ }^{\text {th }}$ August). [advertising] Diário de Lisboa, p. 3.

Três dias sem deus: filme 100\% português dirigido por Bárbara Virgínia (1946b, 30 ${ }^{\text {th }}$ August). [advertising] Diário Popular, p. 9.

Um novo êxito do cinema português: Três dias sem Deus (1946, 31 ${ }^{\text {th }}$ August). [advertising] O Século, p. 3.

Vianna, J. \& Muller, A. (1950). Anto [processo apresentado ao SNI]. Arquivo da Torre do Tombo. Refa ${ }^{a}$ DIV 1245 (Img. Digit. a partir de microfilme) e DIV 1246 (CD), PT-TT-SNI-DGE-22-1-37_cooog a PT-TT-SNI-DGE-22-1-37_CO126.

Vieira, P. (2015). Portuguese film, 1930-1960: the staging of the New State regime. London: Bloomsbury.

Virgínia, B. (1972). A mulher na sociedade: manual prático e ilustrado de charme e distinção. Prior Velho: Editora Paulinas.

Virgínia, B. (1986). Poder pode... mas não deve! manual ilustrado do bem-receber, elegância, charme e etiqueta. São Paulo: Loyola.

Virgínia, B. (1992). Comportamento: dicas para o executivo ter sucesso: a etiqueta dos anos 9o. São Paulo: Loyola.

Virgínia, B. (1993). Etiquetas sem etiqueta: só para teenagers: dicas de relacionamento pessoal. São Paulo: Loyola.

Visor 42 (1946, 31th August). "Três dias sem Deus" no Ginásio. Diário de Lisboa, p. 5.

Xavier, L. (1987, $8^{\text {th }}$ May). Bárbara Virgínia: memórias em São Paulo. Diário de Notícias, p. 18.

Três dias sem deus (1946, $8^{\text {th }}$ March). 7 a Arte: revista mundial de cinema, p. 6.

\section{FiLMOGRAPHY}

Coelho, A. (1947). Aldeia dos rapazes da rua. Lisbon: Secretariado Nacional da Informação. Retrieved from: http://www.cinemateca.pt/Cinemateca-Digital/Ficha.aspx?obraid=2396\&type=Video.

Fonseca, R. F. da (1945). Neve em Lisboa. Lisbon: Invicta Filmes Independente.

Porfírio, C. (1945). Sonho de Amor. Lisbon: Cinelândia.

Virgínia, B. (1946). Aldeia dos rapazes: Orfanato Sta. Isabel de Albarraque. Lisbon: Invicta Filmes. Independente.

Virgínia, B. (1946). Três dias sem Deus. Lisbon: Invicta Filmes Independente. 


\section{WEBGRAPHY}

Delcamp.net (2008, October). Portugal vignette with error perforation religiouse 3 days without god.

Retrieved from: http://www.delcampe.net/page/item/id,45580603,var,PORTUGAL-VIGNETTE-WITH-

ERROR-PERFORATION-RELIGIOUSE-3-DAYS-WITHOUT-GOD, language,F.html

Festival de Cannes. Sélection officielle 1946: en Compétition. Retrieved from http://www.festival-cannes.fr/fr/ archives/1946/inCompetition.html

\section{ACKNOWLEDGMents}

To Bárbara Virgínia's daughter, for her donation of books, photos and personal papers.

To Wiliam Pianco and Ana Catarina Pereira, for sharing the recording of their interview with Bárbara Virgínia, before it was even published.

\section{BiographicAl Notes}

Paula Sequeiros is a postdoctoral researcher at the center of Social Studies, in Universidade de Coimbra, and an associate researcher at the Institute of Sociology, in Universidade do Porto. Degree in History (UP), Master in Society of Information and Knowledge (Universitat Oberta de Catalunya), PhD in Sociology (UP). Her research interests are the sociology of culture and cultural studies on reading and public libraries. Her publications are available in the Open Access repositoryE-LIS.

E-mail: paulasequeiros@ces.uc.pt

Centro de Estudos Sociais, Colégio de S. Jerónimo, Largo D. Dinis Apartado 3087, 3000-995 Coimbra, Portugal

Luísa Sequeira is a filmmaker. She studied journalism and specialized in directing documentaries, worked on TV for ten years at RTP projects, such as Fotograma. She is the artistic director of Shortcutz Porto. She organizes the Super 9 Mobile Film Fest. She directed Quem é Bárbara Virgínia?, Mulheres no Palco, Os Cravos e a Rocha, and the experimental films Memória, substantivo feminino and La Luna. She currently is producing a film about As Novas Cartas Portuguesas and Nada a temer, a documentary co-directed with visual artist Sama, about the current political situation in Brazil.

E-mail: Lusequeira@hotmail.com

Rua Dom António Barroso, 141, 4050-060, Porto, Portugal

* Submitted: 01-08-2017

* Accepted: 04-11-2017 